\title{
Contesting Views of the Philippines and China over the Nine-Dash Line in the South China Sea
}

\author{
Marthen Napang, Farida Patittingi, Zulkifli Aspan, \\ Achmad Ruslan, Birkah Latief, Ruslan Hambali \\ \& Marcel Hendrapati*
}

The PCA's decision refusing historic rights concerning the 9-DL cannot be enforced because the decision advantaging the Philippines has already been rejected by China. It, however, may be as a reference for some states to negotiate, since an optimistic atmosphere emerges among the disputing parties. The readiness for negotiation among them clearly requires that parties should not have rigid attitudes but should show flexibility based on the reciprocity principle. On one side, the PRC should set aside its typical intention to dominate most parts of the South China Sea as its traditional fishing ground based on historic rights concerning the 9-DL. On the other side, the Philippines should guarantee the regional stability and peace without questioning the real sovereignty of the PRC over several natural features, possibly related to the 9-DL claimed as its historic rights. The 9-DL is incompatible with the UNCLOS.

\section{Keywords}

Nine-dash Line, 9-DL, Historic Rights, PCA, Natural Features, Traditional Fishing Ground.

* Marthen Napang, Farida Patittingi, Juajir Sumardi, Zulkifli Aspan, Achmad Ruslan, and Marcel Hendrapati are Lecturers of Law Faculty at Hasanuddin University, Republic of Indonesia. Corresponding author: Marcel Hendrapati. He may be contacted at: mhendrapati@yahoo.com 


\section{Introduction}

Various incidents occurring in the South China Sea, including illegal fishing by foreign fishermen, clearly indicate a fundamental violation of international law by the People's Republic of China ("PRC"). ${ }^{1}$ Such violations or deviations from the United Nations Convention on the Law of the Sea 1982 ("UNCLOS") are related to the PRC's claim over most parts of the regional waters based on historic rights in the past.

Legal and territorial disputes persist especially over the Spratly and Paracel Islands as well as Scarborough Shoal. The scene of ongoing tensions shows between China and the Philippines. ${ }^{2}$ China's claim of historic rights over the South China Sea covers not only most parts of the regional waters, but also all the archipelagoes such as Paracel and Spratly, as well as rocks and the other natural features existing in the region. However, most parts of the waters in the South China Sea constitute the routes of navigation and flight for the international community following the principle of freedom of the high seas under international law. Among them, the Ninedash Line claim of China is the heart of the South China Sea dispute, since Beijing's claim encircles as much as 90 percent of the contested waters.

The line runs as far as 2,000 kilometers from the Chinese mainland to within a few hundred kilometers from the Philippines, Malaysia and Vietnam. Beijing maintains that it owns any land or features contained within the line, which confers vaguely defined "historical maritime rights."3 Some of China's actions seem to support the definition of the line.

1 See Ship Incident in Natuna Sea, People Representative Council: This is a Serious Violation (Insiden Kapal Cina di Natuna, DPR: Ini Pelanggaran Serius!), available at https:/tirto.id/insiden-kapal-cina-di-natuna-dpr-ini-pelanggaranserius-qxC. See also J. Cochrane, Indonesia, Long on Sidelines, Starts to Confront China's Territorial Claims, N.Y. Times, Sept. 10, 2017, available at https:/www.nytimes.com/2017/09/10/world/asia/indonesia-south-china-seamilitary-buildup.html (all last visited on May 20, 2019).

2 China makes the largest claim in the South China Sea, within a 'dash-line' map published by the Kuomintang Government in 1947. See C. Lindemann, The Situation in the South China Sea (SCS), Berlin Model United Nations, Research Report Booklet 19 (2018); Arbitration on the South China Sea: Rulings from The Hague (Jan 22, 2013), available at file://E:/Simposium\%20APHI\%202016/PCA/Arbitration\%20on\%20the\%20South\%20China\%20 (last visited on May 20, 2019).

3 Liu Zhen, What's China's 'Nine-dash line' and why has it created so much tension in the South China Sea?, S. CHINA MorNING Post, July 12, 2016, at 5, available at https:/www.scmp.com/news/china/diplomacy-defence/article/1988596/ whats-chinas-Nine-dash-line-and-why-has-it-created-so (last visited on May 23, 2019). 
Figure 1: Nine-dash Lines ${ }^{4}$

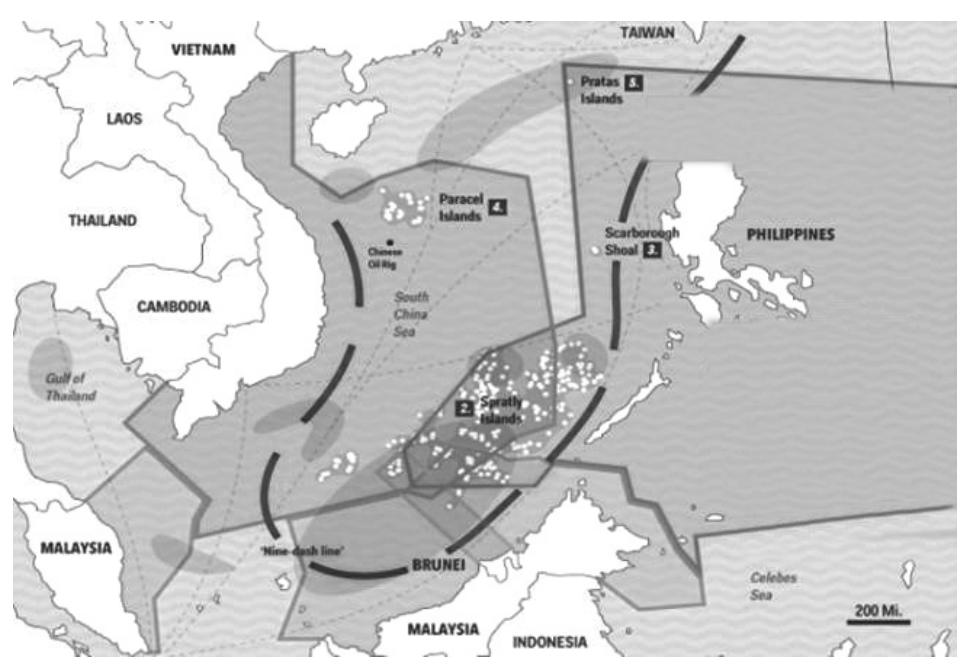

In 2012, a fleet of Chinese maritime surveillance cutters patrolled the South China Sea in what was dubbed a "regular rights defense patrol." A Chinese state TV crew was brought along for part of the ride. Andrew Chubb, a doctoral student at the University of Western Australia who studies Chinese policy on the South China Sea, noted that the route that Chinese ships took, which was documented on state TV, echoed the Nine-dash Line claim. ${ }^{6}$ Chinese audiences would be impressed that the dotted demarcation was the extent of Chinese sovereignty. In 2012, moreover, Chinese boats cut seismic cables used for energy exploration by Vietnam. The cablecutting occurred near the western extent of the Nine-dash Line, again suggesting that these waters were China's. ${ }^{7}$ All these activities by Chinese authorities in the South China Sea would constitute an infringement not only on the freedom of the seas for every state, but also on the sovereignty or sovereign rights of claimant states in the region, particularly the Philippines.

4 Editor Indrawan, Identifying the Nine Dash Line of PRC and the Claim to South China Sea (Mengenal 9 Garis Putus-putus Tiongkok dan Klaim Laut China Selatan), batamnews co.id (Junw 2016), at A1, available at https://www.batamnews.co.id/ berita-14168-mengenal-9-garis-putusputus-tiongkok-dan-klaim-laut-china-selatan.html (last visited on May, 27, 2019).

5 M. Tsirbas, What Does the Nine-Dash Line Actually Mean?, Diplomat, June 2, 2016, available at https://thediplomat. com/2016/06/what-does-the-Nine-dash-line-actually-mean (last visited on May 23, 2019).

6 H. Beech, Just Where Exactly Did China Get the South China Sea Nine-Dash Line From?, Time, July 19, 2016, available at http://time.com/4412191/Nine-dash-line-9-south-china-sea (last visited on May 23, 2019).

$7 \quad$ Id. 
Eventually, the Philippines instituted arbitral proceedings against China at the Permanent Court of Arbitration ("PCA") in 2013. ${ }^{8}$ The Nine-dash Line appeared on a Chinese map as an 11-dash line in 1947 as the then Republic of China's navy took control of some islands in the South China Sea that had been occupied by Japan during the second world war. ${ }^{9}$ After the People's Republic of China was founded in 1949 and the nationalist (Kuomintang) forces fled to Taiwan, the PRC government declared itself the sole legitimate representative of China and inherited all the nation's maritime claims in the region. ${ }^{10}$ But two 'dashes' were removed in the early 1950s to bypass the Gulf of Tonkin as a gesture to communist comrades in North Vietnam. ${ }^{11}$ Beijing intensified its hold on the northern part of the waters in the mid1970s when it expelled the South Vietnamese navy from the Paracel Islands after a clash. Seven out of about 200 reefs in the Spratly Islands came under Chinese control in the 1980s and 1990s as well as Scarborough Shoal in 2012. ${ }^{12}$

The Nine-dash Line is so important because it serves as the basis of China's claim to 'historical rights' in the region, as neither Beijing nor Taipei ever held effective control over the entire region encompassing more than 2 million square kilometers. In the other sense, the Philippines, Malaysia and Brunei root their claims in geographical proximity, while Vietnam, which occupies the largest number of islands and reefs in the Spratlys (29), stresses that it actively administers the area. The Philippines challenged the legality of the line at the International Tribunal under the UNCLOS. ${ }^{13}$

This essay aims to scrutinize the contesting views of the Philippines and the PRC regarding the Nine-dash Line, which is the heart of the dispute in the South China Sea. Furthermore, it also carries out a legal analysis of the Nine-dash Line to determine if it can be connected with any relevant provision of UNCLOS.

\section{The Philippines' View regarding the Nine-dash Line}

After China took control of a reef about 140 miles from the Philippine coast in 2013, the Philippines filed a complaint, accusing China of violating international law

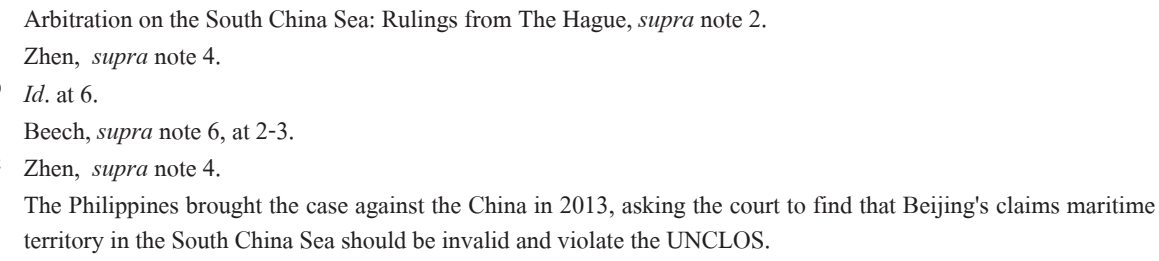


by interfering with fishing, endangering ships and failing to protect the marine environment at the reef, known as Scarborough Shoal. ${ }^{14}$ The Philippines did not go through the International Court of Justice ("ICJ"), since the jurisdiction of the ICJ requires an agreement of the disputing states. Clearly, China would not give its approval regarding the jurisdiction of the ICJ because, since early times, China has stated its wishes for settling the dispute regarding sovereignty and maritime delimitation through dialogue and bilateral negotiations with the respective parties, including the Philippines. ${ }^{15}$

The Philippine Government tried bilateral negotiations with China, but failed to resolve the maritime disputes through dialogue. Finally, the Philippines initiated the arbitration case. The Philippines was very carefully in instituting the proceedings, since the UNCLOS establishes many limitations or prerequisites concerning substances of dispute, which can be invoked. ${ }^{16}$ The Philippines emphasized that the Tribunal could not rule on issues of sovereignty. Instead, it sought an outcome that rejects China's claim on the Nine-dash Line and historic rights. ${ }^{17}$ Article 288 and Article 9 of Annex VII of the UNCLOS address the situation where a party objects to the jurisdiction of a tribunal and declines to participate in the proceedings.

Firstly, Article 288 provides: "In the event of a dispute as to whether a court or tribunal has jurisdiction, the matter shall be settled by a decision of that court or tribunal." Secondly, Article 9 of Annex VII of the convention provides as follows:

If one of the parties to the dispute does not appear before the arbitral tribunal or fails to defend its case, the other party may request the tribunal to continue with the proceedings and make its award. The absence of a party or failure of a party to defend its case shall not constitute a barrier and handicap to the proceedings. Before making its award, the arbitral tribunal must satisfy itself not only that it has jurisdiction over the dispute but also that the claim is well founded in fact and law.

14 Lindemann, supra note 2, at 19.

15 Id. at 4 .

16 On January 22, 2013, the Philippines submitted a Notification and Statement of Claim in order to initiate compulsory arbitration proceedings under Article 287 and Annex VII of the UNCLOS with respect to the dispute with China over 'maritime jurisdiction' in the South China Sea. On February 19, 2013, the Chinese Government rejected and returned the Philippines' note verbale. For details, see The South China Sea Arbitration Awards: A Critical Study (Chinese Society of International Law ed., 2018), available at https://academic.oup.com/chinesejil/article/17/2/207/4995682. See also Position Paper of the Government of the People's Republic of China on the Matter of Jurisdiction in the South China Sea Arbitration Initiated by the Republic of the Philippines, The South China Sea Issue (Dec. 7, 2014), available at https:// www.fmprc.gov.cn/nanhai/eng/snhwtlcwj_1/t1368895.htm (all last visited on May 23, 2019).

17 Press Release: The South China Sea Arbitration (Phil. v. P.R.C.) (Perm. Ct. Arb., Dec 7, 2016), at 4, available at https://pca-cpa.org/wp-content/uploads/sites/175/2016/07/PH-CN-20160712-Press-Release-No-11-English.pdf (last visited on May 23, 2019). 
The Philippines declared that the claims in the South China Sea should be compatible with the UNCLOS, which would invalidate China's Nine-dash Line. ${ }^{18}$ On March 30, 2014, the Philippines submitted its memorial to the arbitral tribunal. The memorial contained its complaints, based on the UNCLOS, which lays out the rules for the use of the world's oceans. ${ }^{19}$ The ten-volume memorial contains the Philippines' legal analysis and evidence to support the case as well as argument that the arbitral tribunal indeed has jurisdiction over the case. ${ }^{20}$

The Philippines further asked the PCA reject China's claim to sovereignty over the waters within the Nine-dash Line. Manila argued that the line exceeds the limits of maritime entitlements permitted under the UNCLOS. ${ }^{21}$ The dashes encircle as much as 90 percent of the South China Sea which is the size of Mexico and is vital to global trade. The Philippines also accused China of violating international law by dredging sand to build artificial islands out of several reefs in the South China Sea, including one it says is in its waters. ${ }^{22}$ The tribunal concluded that China had unlawfully built an artificial island in the Philippine waters and that there was "no legal basis" for the Nine-dash Line. ${ }^{23}$

In December 6, 2014, the US Department of State issued the Limits in the Seas report on China's Nine-dash Line claim. The report of the State Department examines the different perspectives regarding China's Nine-dash Line claim and the legality of each perspective based on the UNCLOS and customary international law. ${ }^{24}$ Regarding the legality of the historic waters claim, the report notes that there is not an effective or continuous exercise of Chinese sovereignty in the region. ${ }^{25}$

4 US Dept. of State, 143 Limits in the Sea (China: Maritime Claim in the South China Sea), Dec. 5, 2014, available at https://2009-2017.state.gov/documents/organization/234936.pdf. See also P. Gewirtz, Limits of Law in the South China Sea, Brookings East Asia Policy Paper 8 (May 2016), available at https://www.brookings.edu/wp-content/ uploads/2016/07/Limits-of-Law-in-the-South-China-Sea-2.pdf(all last visited on May 27, 2019).

25 Supra note 8. 


\section{China's View regarding the Nine-dash Line before the Permanent Court of Arbitration}

In February 19, 2013, China submitted a note verbale rejecting the claims made by the Philippines, as declared in the notification and statement of claim. ${ }^{26}$ China stated that the arbitral tribunal lacks jurisdiction in this case. In August 1, 2013, through a note verbale, China stated that it did not accept the arbitration initiated by the Philippines, so that it would not participate in the proceedings. ${ }^{27}$ In December 7, 2014, the PRC's Ministry of Foreign Affairs issued a position paper on the arbitration case. ${ }^{28}$

The position paper argues that the Philippines' claim is contradicted to their initial notification and statement of claim. Here, China stated that its sovereignty based on historic rights regarding the Nine-dash Line had never been investigated and determined by an international body. Therefore, in China's view, the arbitral tribunal, which has no competence to rule on issues of sovereignty, could not determine the extent of China's maritime rights. ${ }^{29}$ China also argued that by signing the 2002 ASEAN-China Declaration of Conduct for Parties in the South China Sea, the Philippines agreed that bilateral negotiations were the only acceptable means of resolving any dispute in the South China Sea, certainly including the Nine-dash Line, which is the basis of China's historic rights claim. ${ }^{30}$

Further, China argued that the Nine-dash Line emerged in the new order of the postwar international society and came well before the UNCLOS. Beijing said China had accepted the Japanese surrender and reclaimed the region with legal backing and the authorization of the Allies. It argued that the US expressed no objections; at the time the Nine-dash Line claimed as its historic rights was recognized by the Allies, including the US. ${ }^{31}$

Before China ratified the UNCLOS on June 7, 1996, it made many efforts to secure its maritime territory through several arrangements. First, China issued the 1958 Declaration on China's Territorial Sea for the ownership titles to all groups of islands in the South China Sea. Second, China affirmed its sovereignty over all islands as

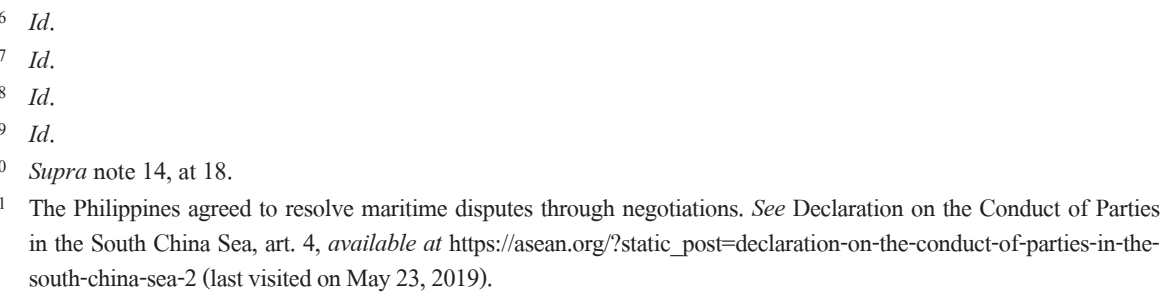
in the South China Sea, art. 4, available at https://asean.org/?static_post=declaration-on-the-conduct-of-parties-in-thesouth-china-sea-2 (last visited on May 23, 2019). 
stated in Article 2 of the Law of the People's Republic of China on the Territorial Sea and the adjacent Zone 1992. The islands are listed in Chinese domestic law including Taiwan, Diaoyu Islands (Senkaku), Xisha Islands (Paracel), Zhongsha Islands (which include Scarborough Shoal), Nansha (Spratly) Islands and all other islands belonging to China. ${ }^{32}$ Such approach was confirmed in the 1992 Law on the Territorial Sea and the Contiguous Zone of the PRC.

According to Article 3 of the Declaration to the UNCLOS, the PRC has reaffirmed its sovereignty over all its archipelagos and islands as listed in the 1992 Law on Territorial Sea and the Contiguous Zone. The Declaration was also included in the Exclusive Economic Zone ("EEZ") and Continental Shelf Act. Article 3 states that China enjoys all rights within these areas and the UNCLOS should not affect its historical rights. ${ }^{33}$ In 2006, China made a declaration under Article 298 of the UNCLOS and does not accept compulsory procedures over certain disputes concerning maritime delimitation, military activities and law enforcement activities. China asserted its historic rights on the Nine-dash Line as follows: ${ }^{34}$

China claims rights to living and non-living resources within the 'Nine-dash line' but (apart from the territorial sea generated by any islands) does not consider that those waters form part of its territorial sea or internal waters.

Chinese scholars suggest the "three layered theory." sovereignty over all the features within the lines on the map and the historic rights are added to the UNCLOS. Such rights would be fishing, navigation, exploration and exploitation of resources. The Nine-dash Line may also be a maritime boundary, as if it was delimited as a median line between the islands and the coastline. ${ }^{36}$

Finally, China and the Philippines reached a bilateral agreement on the Nine-dash Line, namely: (1) 2002 Declaration on the Conduct of Parties in the South China Sea (DOC); (2) 2004 March 2005 The Philippines and the People's Republic of China the Spratly archipelago together, as well as working together with fishing in the area; (3) Viet Nam, the PRC, and the Philippines sign an 'Agreement for Joint Marine Seismic

32 K. Malczewska, China's Claim to the South China Sea under International Law, at 69, available at http://dspace.uni. lodz.pl/xmlui/bitstream/handle/11089/12510/6-067_080-Malczewska.pdf?sequence=1\&isAllowed=y (last visited on May 23, 2019).

33 Id.

34 T. McDorman, The South China Sea Arbitration: Selected Legal Notes, 21 Asian Y.B. InT'L L. (2015), available at https://brill.com/configurable/contentpage/book\$002fedcoll\$002f9789004344556\$002fB9789004344556_002. xml\#container-12938-item-12941 (last visited on May 23, 2019).

35 Supra note 4.

36 Supra note 1. 
Undertaking in the Agreement Area in the South China Sea." Together with one oil enterprise per signatory country, the treaty determines the states' cooperation in the research of oil in an agreed area, but the agreement broke down when the case was brought to arbitration. ${ }^{37}$ China maintained that the initiation of unilateral action by the Philippines through arbitration clearly violates international law. It repeatedly stated that China would neither accept nor participate in the arbitration unilaterally initiated by the Philippines. ${ }^{38}$

\section{Legal Analysis regarding the Nine-dash Line}

China is a party to the UNCLOS. However, it has never given a legal definition or meaning of the Nine-dash Line. This made various interpretations, ${ }^{39}$ particularly when coupled with some other actions that China has taken in response to perceived incursions within the area bounded by that line. ${ }^{40}$ Such ambiguity has caused many ordinary Chinese people to think that it marks 'the nation's maritime boundary."

Others say that the line encircles the area where China demands 'economic rights. ${ }^{41}$ Another interpretation is that the line marks 'the islands and reefs China wants to control rather than the waters inside its boundaries." ${ }^{42}$ Beijing has long favored a strategy of ambiguity. It does not openly go against international law, but prefers to leave space for its more ambitious claims. From a legal point of view, the line does not make much sense because it appears to be a conflation of the concepts of sovereignty and jurisdiction. No coordinates for islands or baselines have been

37 Id. at 77.

38 Supra note 17 , at 1 . See also supra note 14 , at 18.

39 Many writers in China categorize the grounds and legal interpretations of the dash line (Chinese and Taiwanese) into the following four viewpoints: (1) the line serves as the 'line of attribution' of the islands therein or that the line is drawn on the map in order to display the will or intention regarding the occupation of the islands within the dash line; (2) the line delineates the 'scope of the historical rights', indicating the realm in which the rights to conduct fishery and develop resources have historically been exercised; (3) the line limits "the historic waters," which indicates the bounds to which China's sovereignty historically and traditionally reaches; and (4) the line is the "traditional border line," according to which the traditional sphere of Chinese influence is delineated. See Taisaku Ikeshima, China's Dash Line in the South China Sea: Legal Limits and Future Prospects, 10 WASEda Global F. 18-21 (2013), available at https:// core.ac.uk/download/pdf/144455129.pdf (last visited on May 23, 2019).

40 M. Tsirbas, What Does the Nine-Dash Line Actually Mean?, DiPlomat, June 2, 2016, available at https://thediplomat. com/2016/06/what-does-the-Nine-dash-line-actually-mean (last visited on May 23, 2019).

41 Zhen, supra note 4. China is a signatory to the UNCLOS, but it has never defined the legal meaning of the Nine-dash line or what its 'rights' are within the boundary.

42 Id. 
provided, whereas the UNCLOS obliges China to establish the coordinates of the line.

The concept of state sovereignty is related to ownership of property nationally, whil the concept of jurisdiction is equated to the ability to benefit from or license the use of natural resources within the EEZ. Nevertheless, a state can neither impose any condition on navigation, nor control over all activities within that area. China would not maintain this is what they mean with the Nine-dash Line. However, some of its conduct and rhetoric really indicate the will of the state to control the freedom of navigation and overflight within the South China Sea. ${ }^{43}$ China might regard the Nine-dash Line as a 'box' of claiming sovereignty over any high-tide elevation and jurisdictional rights on any corresponding maritime zone (e.g., territorial sea, EEZ or continental shelf) generated by that feature. ${ }^{44}$

The principal jurisdictional question concerning the Nine-dash line and possible Chinese historic rights therein was whether such a claim was captured by the wording of the UNCLOS, Article 298(1)(a)(i) “... disputes ... involving historic bays or title." China had not directly raised the "historic bays or title" exemption in the "Position Paper" of December 2014. ${ }^{45}$ The principal issue on the merits was the relationship between the historic rights asserted by China as existing within the Ninedash line and the rights of the Philippines based on the UNCLOS in areas where the claimed historic rights were beyond China's $200 \mathrm{~nm}$ EEZ or continental shelf and within the EEZ/continental shelf of the Philippines. ${ }^{46}$

To deal with both the jurisdictional and merits questions, it was necessary for the Tribunal to assess what was being claimed by China within the Nine-dash line; in other words, what was "the nature of any historic rights claimed by China" within the Nine-dash line. According to the ruling, China is pressed to clarify its position on the line's legal justification. China seems not remove the line from its maps. ${ }^{47}$ Beijing has repeatedly said that it would ignore any ruling by the arbitral tribunal. Meanwhile, Taiwan's leader, Tsai Ing-Wen has not mentioned the 9 or 11-Dash line, but she has emphasized that it would adhere to international law. If Tsai were to give up the Nine-dash line claims following the ruling, cross-strait relations would likely be further strained. ${ }^{48}$ Regarding Taiwanese Position after the PCA Award,

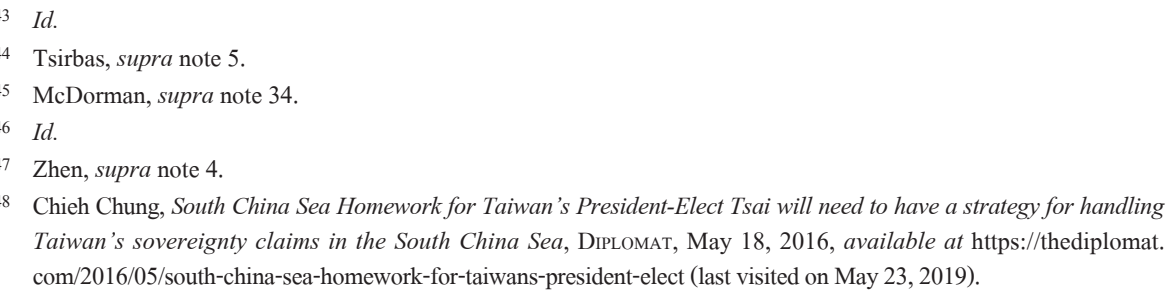


the Presidential Office spokesman Alex Huang has stated: "We hereby stress that Republic of China (ROC) enjoys rights as afforded by international law and the UNCLOS over South China Sea islands and their relevant waters. Rejecting the verdict of PCA, Foreign Minister of Taiwan David Tawei Lee stated it was totally unacceptable." 49 The Cabinet spokesperson Tung Chen-Yuan stated [Taipei will] strengthen its Coast Guard patrols in order to protect its fishermen (on Taiping Island). ${ }^{50}$

The Nine-dash Line would take over areas of the South China Sea that should be subject to the sovereignty of the Philippines, Malaysia, Brunei and Vietnam. ${ }^{51}$ Especially for Indonesia, one of these imaginary dashes actually extends into its EEZ in the Natuna Sea, while, in view of China, the Natuna Sea is a part of China's traditional fishing ground. A number of incidents involving Indonesia and China in the Natuna Sea around 2016 brought about them to send diplomatic notes of protest to each other. All the incidents originated from the historic rights claim relating to the Nine-dashed Line.

\section{Conclusion}

The Philippines conducted bilateral negotiations with China to settle maritime disputes, especially regarding the Nine-dash Line, but failed. The Philippines had no option but to initiate the arbitration case by utilizing the UNCLOS mechanism, which ensures jurisdiction of the PCA to resolve the Nine-dash Line. China was not present during the arbitration proceedings since it did not accept the jurisdiction of the court. China refuses the jurisdiction because the Nine-dash Line is related to the questions of sovereignty and maritime delimitation. Nevertheless, the absence of China does not constitute a barrier to the proceedings of arbitration. Although the tribunal could not rule on issues of sovereignty, the Philippines asked it to reject China's claim to sovereignty over waters within the Nine-dash line.

The PCA invoked a document issued by China's Ministry of Foreign Affairs in

49 Yen-Chiang Chang, Taiwanese Position in the South China Sea Dispute: Before and After the Permanent Court of Arbitration Award, 9 J. EAst AsIA \& INT'L L. 474 (2016).

50 Id.

51 A. Kusumadewi \& R. Suastha, Republic of Indonesia Must be on Guard against the Impact of the Permanent Court of Arbitration's Decision Regarding the South China Sea (RI Mesti Mewaspadai Dampak Putusan Arbitrase Laut Cina Selatan), CNN InDONESIA, Aug. 8, 2016, available at http://www.cnnindonesia.com/nasional/20160703151959-20-142745 (last visited on May 20, 2019). 
2014, which constitutes a position paper on the arbitration case. In principle, this document is a reiteration of comments in the note verbale of 2013, stressing that China's own sovereignty over the maritime features in question existing within the Nine-dash Line has never been investigated and decided by an international body. Therefore, in its opinion, the arbitral tribunal has no jurisdiction to rule on issues of sovereignty and cannot determine the scope of maritime rights. In 2002, the ASEANChina Declaration of Conduct for Parties in the South China Sea agreed that bilateral negotiations were the only acceptable means of resolving any dispute in the South China Sea, including the Nine-dash Line claimed as 'historic rights' by China.

In July 2016, the Permanent Court of Arbitration ruled that China had no legal basis to claim the area within the Nine-dash Line since China did not define the territory precisely. China has never proposed a definition of the Nine-dash Line, whether the line marks the nation's maritime boundary or it marks the islands and reefs China wants to control rather than the waters inside its boundaries. This situation results in multiple interpretations and is a strategy of ambiguity favored by Beijing to gain ambitious claims. 
